\title{
Peran Kebijakan Pemerintah Dalam Memperkuat Aliansi Strategis Dan Meningkatkan Daya Saing Ekonomi Kreatif
}

\author{
Umu Khouroh*, Irany Windhyastiti, Krisnawuri Handayani \\ Fakultas Ekonomi dan Bisnis, Universitas Merdeka Malang, Indonesia \\ *umukhouroh@yahoo.com
}

\begin{abstract}
This study aims :1) to examine the effect of strategic alliances and government policies on the achievement of competitive advantage of micro, small and medium creative enterprises, 2) to assess the role of government policies in moderating the relationship between strategic alliances and competitive advantage. This study was conducted in 130 micro, small and medium craft enterprises in Malang Raya. Using SEM-PLS in WarpPLS 6.0, this study finds that strategic alliances have significant effects on competitive advantage. Government policy does not moderates the relationship between strategic alliances and competitive advantage, but at the same time it serves as the driver of strategic alliances and the predictor of competitive advantage. Government policies have the highest loading factor, followed by strategic alliances. Thus, micro, small and medium enterprises in creative economy must focus on optimizing strategic alliances to greatly improve their competitive advantage. In addition, the government can driven strategic alliances while providing facilitation, support, and policies that encourage improvements in competitive advantage.
\end{abstract}

Keywords: Strategic Alliances, Government Policy, Competitive Advantage

\section{PENDAHULUAN}

Era revolusi industri 4.0 menjadikan ekonomi kreatif salah satu isu strategis yang layak mendapatkan perhatian utama. Fakta menunjukkan bahwa perusahaan harus mengandalkan SDM yang lebih kreatif. Perusahaan memerlukan kreativitas tinggi agar mampu menciptakan produk inovatif. Dari poin inilah, eksistensi ekonomi kreatif muncul dan berkembang (Salman, 2010).

Sektor ekonomi kreatif, menjadi pilihan strategis untuk memenangkan persaingan global, yang ditandai dengan tingginya inovasi dan kreativitas guna meningkatkan nilai tambah ekonomi dan daya saing melalui kapitalisasi ide kreatif. Ekonomi kreatif di Indonesia telah memberikan kontribusi yang signifikan dalam perekonomian nasional. Badan Pusat Statistik (BPS) melansir beberapa prestasi sektor ekonomi kreatif pada Tahun 2016 diantaranya: 1) memberikan kontribusi 7,44 persen terhadap PDB dengan nilai PDB 922,59 trilyun 2) Tumbuh 4,95 persen naik sebesar 0,54 persen; 3) Unit usaha mencapai 8,2 juta unit 4) Penyerapan tenaga kerja sebesar 16,91 juta pekerja atau sekitar 14,28 persen dari total jumlah tenaga kerja nasional (118,41 juta). 5) ekspor tercatat senilai US $\$ 19,98$ milyar dengan kontribusi ekspor 13,77 persen dari total ekspor nasional.

Merujuk pada angka-angka tersebut, ekonomi kreatif memiliki posisi penting dan sangat berpotensi untuk dikembangkan di Indonesia. Namun dalam konteks penciptaan nilai tambah, ekonomi kreatif menghadapi 
banyak faktor yang bisa menghambat pertumbuhannya, yang berhubungan dengan 1) rendahnya profesionalitas, baik dari segi keterampilan, skill, pengetahuan, sikap dan perilaku, serta terbatasnya akses bekerjasama dan mengembangkan jaringan baik lokal, nasional, dan global; 2) Jumlah usaha kreatif di Indonesia lebih rendah jika dibandingkan dengan negara yang industri kreatifnya telah berkembang; 3) Kesadaran pasar akan produk dan karya kreatif di Indonesia masih relatif rendah meskipun keunikan dan kreativitas karya dan produk kreatif diakui oleh pasar global (Kemenparekraf, 2014). Hasil kajian BPS (2015) juga menunjukkan bahwa sektor usaha ekonomi kreatif, menghadapi permasalahan yang tidak jauh berbeda dengan UMKM lainnya yaitu: 1) pemasaran; 2) riset dan pengembangan; 3) infrastruktur; 4) regulasi dan HaKI; 5) akses keuangan dan 6) kelembagaan.

Mengacu pada potensi dan hambatan dalam pengembangan ekonomi kreatif, untuk menjadikan ekonomi kreatif sebagai salah satu mesin pertumbuhan ekonomi di Indonesia, ada tujuh tantangan utama yang dihadapi yaitu, 1) penyediaan sumberdaya kreatif yang berdaya saing, profesional, dan merata; 2) penyediaan sumberdaya pendukung yang bermutu, beragam, dan berdaya saing; 3) penguatan struktur industri yang kompetitif, berkembang, dan beragam; 4) penyediaan pembiayaan yang tepat dan sesuai, bersaing, dan merata; 5) perluasan pasar bagi karya kreatif di tingkatan lokal maupun global; 6) penyediaan infrastruktur teknologi yang bersaing, sesuai, dan dengan mudah dapat diakses oleh orang kreatif, dan 7) penguatan kelembagaan yang memberikan dukungan bagi pengembangan ekonomi kreatif (Bekraf, 2017).

Permasalahan dan tantangan

pengembangan ekonomi kreatif serta era revolusi industri 4.0 dan disruptive innovation menuntut UMKM ekonomi kreatif mencari sumber keunggulan bersaing dan terlibat dalam persaingan baru guna meningkatkan daya saing dan keunggulan bersaing. Hal ini pada gilirannya, membutuhkan pemahaman yang jelas tentang sifat dan dinamika persaingan (Denisi et al., 1998).

Secara konseptual, pendekatan yang populer dalam memahami dinamika persaingan dan cara terbaik mencapai keunggulan bersaing dari perspektif yang berbeda adalah Industrial Organizational-I/O Theory dan Resources-Based View (RBV). I/O Theory memandang keunggulan bersaing diperoleh dengan mempertahankan dan memposisikan diri dalam posisi yang menarik dan terus menerus menjaga diri dari pesaing saat ini dan pesaing potensial dengan membangun dan memanipulasi hambatan masuk dan mobilitas. (Porter, 1980; Caves dan Ghemawat, 1992). Sementara itu Resources-Based View (RBV) memberikan penjelasan bahwa perusahaan memiliki keunggulan bersaing ketika tidak secara bersamaan menerapkan sebuah strategi penciptaan nilai dengan yang diterapkan oleh pesaing saat ini atau pesaing potensial. Empat atribut utama-valuable, rare, nonimitable, sumberdaya dan kemampuan spesifik perusahaan merupakan sumberdaya ekonomi perusahaan (Barney, 1991) Bharadwaj et al. (1993) juga mengemukakan perusahaan yang mempunyai keunggulan bersaing mempunyai aset, nilai dan kecakapan unik sebagai sumber keunggulan bersaing. Keakuratan dan ketepatan mengidentifikasi sumberdaya dan kapabilitas unik sebagai kompetensi inti merupakan basis keunggulan bersaing, keunggulan strategi dan kemampuan untuk memperoleh above-average return (Hitt et al., 2011).

Meskipun berbeda perspektif, Bridoux (2004) mengenali bahwa RBV dan I/O Theory saling melengkapi dan dapat diintegrasikan dalam kerangka kerja yang menjadi sumber dari kinerja dan strategi khususnya perilaku bersaing untuk memperoleh keunggulan bersaing. Melalui kombinasi efektif dari penggunaan model I/O dan model RBV, perusahaan-perusahaan secara dramatis akan dapat meningkatkan profitabilitas dengan mencapai daya saing strategis, menghasilkan laba diatas rata-rata dan memperoleh keunggulan bersaing berkelanjutan (Hitt et al., 2001) 
Sektor ekonomi kreatif berbasis pada ide, kreativitas, dan inovasi sebagai alat untuk menciptakan keunikan yang menjadi ciri khasnya. Ekonomi kreatif menjadi salah satu solusi ketika perusahaan dihadapkan pada kelangkaan sumberdaya. Kreativitas menjadi modal utama untuk menghasilkan produk terbaik dan inovasi berkelanjutan. UMKM ekonomi kreatif yang ingin mencapai keunggulan bersaing harus menggunakan kreativitasnya dan melakukan inovasi agar mampu menghasilkan produk yang berbeda dengan pesaingnya. Perbedaan produk ini harus terefleksikan oleh konsumen, artinya konsumen merasakan perbedaan tersebut secara nyata yang berarti bahwa keunggulan bersaing akan bergantung pada kemampuan beradaptasi dengan kebutuhan konsumen (Treacy dan Wiersema, 1993).

Fakta menunjukkan bahwa bagi kebanyakan perusahaan terutama UMKM termasuk usaha ekonomi kreatif yang memiliki banyak keterbatasan seperti akses pembiayaan, terbatasnya pemasaran, kemampuan manajemen dan teknologi yang rendah dan kelembagaan yang belum maksimal (BPS, 2015), sangatlah tidak mungkin memiliki semua kemampuan, sumberdaya, dan kompetensi inti yang diperlukan untuk bersaing dengan sukses di arena persaingan yang kompetitif dalam jangka waktu yang panjang. Keterbatasan tersebut menuntut usaha ekonomi kreatif untuk melakukan aliansi strategis.

Aliansi menjadi semakin umum karena globalisasi dan percepatan laju perubahan teknologi. Perusahaan dapat membentuk dan mereformasi aliansi dengan pemangku kepentingan untuk mengakses dan mengelola sumberdaya yang berharga, bergerak, dan langka untuk bertahan dalam persaingan di lingkungan yang dinamis (Teece et al., 1997). Pembentukan aliansi strategis juga dimotivasi untuk meningkatkan skill dan teknologi (Hamel et al., 1989; Palakshappa dan Gordon, 2007), penyebaran teknologi baru dengan cepat dan efektif, atau untuk mempelajari sesuatu dari perusahaan yang lebih unggul (Dyer et al., 2001) meningkatkan pembelajaran tentang penggunaan teknologi baru (Lei et al., 1997) memperoleh akses sumberdaya yang bersifat komplementer dan menggabungkan sumber keahlian (Hitt et al., 1997).

Dinamika Revolusi Industri 4.0, mengharuskan UMKM ekonomi kreatif meningkatkan pengelolaan usaha dengan melibatkan multistakeholder. Untuk membuka potensi pengembangan ekonomi kreatif secara global, dibutuhkan kemauan yang lebih besar bagi para stakeholder untuk berkolaborasi dan bersama-sama merancang pendekatan baru guna mengantisipasi perkembangan teknologi dan membangun rasa saling percaya. UMKM ekonomi kreatif di Indonesia telah menjalin kemitraan dengan berbagai stakeholder untuk mengembangkan usahanya diantaranya dengan perusahaan swasta, instansi pemerintah, perbankan, BUMN/BUMD dan yayasan/LSM. Jenis kemitraan yang dibangun terkait dengan pemasaran, mesin dan peralatan, pengadaan bahan baku, uang/barang modal dan lainya (Bekraf, 2016). Motif aliansi strategis yang dibangun UMKM ekonomi kreatif ini sejalan dengan pendapat Varadarajan dan Cunningham (1995) yang menyatakan ada beberapa motif perusahaan melakukan aliansi strategis yaitu masuk kepasar internasional baru, mengatasi hambatan memasuki pasar baru, melindungi posisi bersaing, memperluas atau mengisi gap lini produk, memasuki domain pasar produk baru/ mendapatkan pijakan di Industri yang sedang berkembang, mempertajam struktur industri, mengurangi ancaman potensial persaingan masa mendatang, meningkatkan dan mengatasi hambatan masuk, meningkatkan efisiensi dan memperluas sumberdaya dan memperoleh keterampilan baru.

Defee (2006) menyatakan bahwa aliansi strategis merupakan sarana UMKM bisa upgrade kemampuan dan mengatur cara untuk tumbuh di masa depan. Penggunaan berkelanjutan dari aliansi strategis akan mengembangkan dan menciptakan pengetahuan. Kanter (1994) menyatakan bahwa keberhasilan aliansi bertumpu pada rasa kesatuan dan kebersamaan melalui proses penciptaan nilai bersama-sama, bukan 
sekedar proses pertukaran atas sejumlah nilai investasi tertentu Hal ini menunjukkan bahwa keberhasilan suatu aliansi membutuhkan kesediaan memberi dan menerima dari pihak-pihak yang beraliansi dan tantangannya adalah seberapa besar toleransi yang dapat diberikan kepada pihak luar untuk mengendalikan bisnis bersama.

Beberapa peneliti menemukan bahwa selain memberikan banyak manfaat, kolaborasi tidak selamanya mampu meningkatkan kinerja dan gagal (Park dan Ungson, 2001; Zineldin dan Dodourova, 2006). Palakshappa dan Gordon (2007) juga menemukan dalam penelitiannya bahwa perusahaan tidak mampu merealisasikan keuntungan dari kegiatan kolaborasi karena tidak mampu mendapatkan ketrampilan dan kompetensi baru dari kegiatan kolaborasi.

Perusahaan yang mengandalkan pada aliansi strategis untuk membangun keunggulan bersaing tanpa melihat bahaya ketergantungan dalam jangka panjang terhadap partnernya akan memperlemah kemampuannya untuk mempelajari atau meraih skill baru (Lynch, 1990). Hal ini terjadi karena partner tidak memiliki kesamaan persepsi yang utuh sehingga timbul kesulitan dalam penggabungan operasi atau tidak mempunyai motivasi yang sama. Aliansi strategis dalam proses pencapaian tujuan mengalami pergeseran, pasar, produk dan komitmen mereka mengalami perubahan. Menghadapi hal tersebut, manajer yang merencanakan aliansi harus memiliki argumentasi yang kuat bahwa kontribusi positif lebih besar daripada potensi masalah yang muncul.

Bagi usaha ekonomi kreatif di Indonesia, untuk mencapai keunggulan bersaing selain membutuhkan aliansi strategis juga perlu peran pemerintah untuk pengembangan usaha. Banyak proposisi dari literatur yang menyatakan bahwa peran pemerintah melalui rangkaian kebijakan ekonomi untuk mempertahankan iklim yang kondusif membantu UMKM beroperasi dengan sukses dan menguntungkan (Dandago dan Usman, 2011; Jasra et al., 2011). Pemerintah dalam konteks pengembangan ekonomi, harus mengambil langkah spesifik untuk memberikan kondisi yang kondusif dalam memajukan UMKM guna menciptakan peluang munculnya berbagai sektor ekonomi dan usaha (Eniola dan Entebang, 2015).

Di negara maju, kebijakan pemerintah adalah faktor yang menentukan pertumbuhan UMKM (Le dan Nguyen, 2009). Karakter dan rentang kebijakan pemerintah membawa dampak pada kinerja. Namun beberapa penelitian yang dilakukan di negara sedang berkembang menunjukkan bahwa kebijakan pemerintah menimbulkan kesan eksploitasi UMKM, hubungan dan jaringan sehingga dapat menjadi penghalang pemanfaatan kekuatan dan sumberdaya (Harvie et al., 2010; Okpara, 2011). Temuan ini sejalan dengan pendapat (Sathe dan HandleyScharchler, 2006) yang menyatakan bahwa peraturan pemerintah dan prosedur birokrasi bisa menghambat sekaligus memfasilitasi kegiatan kewirausahaan bisnis baru. Pemerintah dapat membuat kebijakan yang dapat meningkatkan dan mendukung pertumbuhan teknologi baru, produk, dan solusi. Di sisi lain, pemerintah juga bisa menghambat kinerja ketika memperkenalkan kebijakan yang dapat membatasi otonomi, serta kebebasan berwirausaha apalagi bagi usaha dengan pertumbuhan dan lingkungan yang sangat dinamis.

Di Indonesia, pemerintah memainkan peran strategis dalam pengembangan usaha ekonomi kreatif. Prinsip ConnectCollaborate-Commerce (3C) menjadi sarana pemerintah untuk memetakan dan mengembangkan potensi ekonomi kreatif di daerah dengan melibatkan unsur pentahelix (Academician, Businesses, Community, Government, dan Media).

Berdasarkan latar belakang dan fenomena usaha ekonomi kreatif, penelitian ini menjadi hal yang penting jika dikaitkan dengan berbagai tantangan, permasalahan dan tuntutan agar UMKM ekonomi kreatif merumuskan strategi bersaing secara tepat untuk mencapai keunggulan bersaing antara lain: 1) Bagi UMKM kreatif yang menghadapi permasalahan pemasaran; riset 
dan pengembangan; infrastruktur; regulasi dan HaKI; akses keuangan dan kelembagaan, maka sangat sulit untuk bisa mengembangkan usaha dan menguasai pasar dengan kekuatan sendiri tanpa melibatkan aliansi strategis dengan pihak lain. Kebutuhan untuk berkolaborasi dan merancang pendekatan baru semakin besar bagi stakeholder yang berbeda guna mengantisipasi perkembangan teknologi dan digitalisasi serta membangun rasa saling percaya antar stakeholder; 2) Kelemahan dan kekurangan dalam implementasi aliansi strategis antara usaha kecil dengan pihak lain dapat diminimalkan dengan dukungan dan kebijakan pemerintah. Peran pemerintah untuk menavigasi ekonomi kreatif semakin dibutuhkan dengan pendekatan yang berbeda. Adopsi konsep pentahelix yang melibatkan akademisi, pengusaha, komunitas pemerintah, dan media menjadi salah satu prasyarat dalam peningkatan daya saing usaha ekonomi kreatif.

Berdasarkan aspek pengembangan konsep dan teori, beberapa alasan yang menjadi dasar dilakukan penelitian ini adalah : 1) Mengisi research gap penelitian sebelumnya yaitu kontradiksi hasil penelitian pengaruh aliansi strategis terhadap keunggulan bersaing dan kontradiksi hasil penelitian pengaruh kebijakan pemerintah terhadap keunggulan bersaing Reserarh gap ini diisi dengan menjadikan variabel kebijakan pemerintah sebagai variabel moderasi. 2) Mengembangkan model penelitian integrasi variabel aliansi strategis dan kebijakan pemerintah dalam pencapaian keunggulan bersaing. Bahwa untuk meningkatkan keunggulan bersaing UMKM ekonomi kreatif selain dipengaruhi oleh aliansi strategis juga diperlukan kebijakan pemerintah sebagai variabel moderasi yang akan memperkuat hubungan tersebut serta mengintegrasikan strategi bisnis berbasis posisi pasar (I/O Theory), berbasis sumberdaya (RBV) dan konsep keberlanjutan.

Aliansi Strategis dan Keunggulan Bersaing Kemenparekraf (2014) menjelaskan bahwa dalam konteks penciptaan nilai tambah, ekonomi kreatif menghadapi banyak faktor yang bisa menghambat pertumbuhannya, yang berhubungan dengan 1) rendahnya profesionalitas, 2) rendahnya jumlah usaha kreatif di Indonesia; 3) kesadaran pasar mengenai produk dan karya kreatif di Indonesia masih relatif rendah.

Hambatan dan keterbatasan UMKM ekonomi kreatif menguatkan fakta bahwa UMKM ekonomi kreatif tidak mungkin mempunyai semua sumberdaya dan kompetensi inti yang dibutuhkan untuk memenangkan persaingan yang kompetitif dalam jangka panjang. Salah satu upaya yang dapat dilakukan untuk mengatasi keterbatasan dan hambatan tersebut adalah dengan aliansi strategis yaitu kolaborasi untuk menjalin bekerjasama dan membangun jaringan. Aliansi diartikan sebagai hubungan kerjasama yang dibangun untuk membangkitkan kemampuan stratejik dan operasional perusahaan untuk mencapai peningkatan kinerja yang signifikan dari tiaptiap perusahaan tersebut (Monczka et al., (1998). Aliansi bisnis merupakan usaha kolaborasi antara dua atau lebih perusahaan dimana perusahaan menyatukan sumberdaya yang dimiliki dalam upaya untuk tujuan yang saling menguntungkan yang tidak bisa dicapai jika sendirian (Lambe et al., 2002; Wittmann et al. 2009)

Kolaborasi dan jaringan dapat dilakukan antar usaha dalam industri kreatif maupun dengan industri lainnya di tingkatan lokal, nasional, dan global yang memungkinkan terjadinya alih pengetahuan dan pengalaman dalam membuat karya dan produk. Kolaborasi dan jaringan yang dikembangkan akan membantu untuk meningkatkan kualitas dan kapasitas usaha kreatif serta meningkatkan daya saing dan keunggulan bersaing.

Pilihan untuk menjalin aliansi strategis dengan sejumlah manfaat tersebut sejalan dengan pendapat Bleeke dan Ernst (1991) yang menyatakan bahwa pembentukan kerjasama dan aliansi strategis adalah untuk mendapatkan keunggulan bersaing di pasar. Aliansi strategis 
merupakan kunci keberhasilan bersaing (Ohmae, 1986) dan merupakan solusi bagi perusahaan untuk mendapatkan keunggulan bersaing (Hamel et al., 1989). Teng (2007) menyatakan bahwa aliansi strategis adalah pilihan logis untuk mengisi kesenjangan sumberdaya dan membantu mencapai keunggulan bersaing dan menciptakan nilai. Ireland et al. (2002) melihat aliansi strategis sebagai kendaraan utama pertumbuhan dan menghasilkan nilai pasar perusahaan. Aliansi strategis menciptakan dua jenis keunggulan bersaing yaitu menciptakan nilai melalui penggabungan sumberdaya dan mengelola portofolio aliansi untuk mencapai keunggulan bersaing.

Menurut Hamel et al. (1989), agar dapat memenangkan persaingan global, perusahaan harus melakukan kolaborasi dengan pesaingnya guna memperkuat posisi pasar. Perusahaan yang bekerjasama dengan pesaingnya akan memperoleh manfaat dalam bentuk peningkatan keahlian dan teknologi serta transfer keunggulan bersaing dari pesaingnya. Berdasarkan uraian diatas, maka dibangun hipotesis sebagai berikut :

$\mathrm{H}_{1}$ : Meningkatnya aliansi strategis akan meningkatkan keunggulan bersaing

\section{Kebijakan pemerintah, aliansi strategis dan keunggulan bersaing}

Bagi UMKM ekonomi kreatif di negara sedang berkembang sangat sulit untuk bisa mengembangkan usaha tanpa melibatkan aliansi strategis dengan pihak lain. Kelemahan dan kekurangan dalam aliansi strategis antara usaha kecil dengan pihak lain dapat diminimalkan dengan keterlibatan pemerintah. Kebijakan pemerintah merupakan tindakan pemerintah dan niat yang menentukan tindakan tersebut (Cochran et al., 2005). Woll (1966) menyatakan bahwa kebijakan pemerintah merupakan aktivitas pemerintah untuk memecahkan masalah di masyarakat, baik secara langsung maupun melalui lembaga yang mempengaruhi kehidupan masyarakat. Mengadopsi konsep pentahelix yang banyak muncul di negara sedang berkembang sebagai upaya penciptaan wirausaha dan pengembangan pengetahuan, maka dukungan aliansi strategis antara usaha kecil, dunia bisnis, komunitas, pemerintah dan media menjadi salah satu prasyarat dalam peningkatan daya saing.

Banyak proposisi dari literatur yang menyatakan bahwa peran pemerintah dibutuhkan, melalui rangkaian kebijakan ekonomi dalam pasar dengan persaingan yang tajam untuk mempertahankan iklim yang kondusif agar UMKM dapat beroperasi dengan sukses dan menguntungkan (Dandago dan Usman, 2011; Jasra et al., 2011). Kang dan Park (2012) menunjukkan bahwa kemitraan hulu secara signifikan terkait dengan inovasi UMKM. Dukungan pemerintah melalui pendanaan proyek secara langsung dan tidak langsung mempengaruhi inovasi perusahaan dengan merangsang kolaborasi $\mathrm{R}$ dan $\mathrm{D}$ internal. Dandago dan Usman (2011) menjelaskan bahwa kebijakan industrialisasi menumbuhkan UKM. Upaya yang ekstensif dalam perumusan ulang kebijakan dan implementasi strategi yang menekankan perlunya dukungan pemerintah yang berkelanjutan terhadap industri skala kecil diperlukan untuk mengangkat negara ke posisi terdepan. Jasra et al. (2011) menyimpulkan bahwa dukungan pemerintah memiliki dampak positif dan signifikan terhadap kesuksesan bisnis. Pengusaha juga belum puas dengan dukungan pemerintah sehingga pemerintah harus memainkan peran penting dengan memberi mereka lingkungan yang kondusif dan menciptakan iklim yang baik. Kebijakan yang mengarah pada keberhasilan usaha yaitu kemudahan mendapatkan izin usaha dan skema pendanaan dari pemerintah. Pemerintah harus memulai program pelatihan bebas biaya terutama bagi pengusaha kecil untuk peningkatan keterampilan pengusaha kecil.

Okpara (2011) mengungkapkan bahwa kendala umum penghambat pertumbuhan dan kelangsungan hidup usaha kecil adalah kurangnya dukungan keuangan, manajemen yang buruk, korupsi, kurangnya pelatihan dan pengalaman, infrastruktur yang buruk, keuntungan rendah, dan rendahnya permintaan akan produk dan layanan. Oleh 
karena itu dengan memahami faktor-faktor tersebut akan membantu pembuat kebijakan dan pemangku kepentingan lainnya merancang kebijakan dan program yang akan merangsang inovasi.

Kemenparekraf (2014) menyatakan ada lima pilar dalam pengembangan ekonomi kreatif yaitu, 1) sumber daya kreatif berupa sumber daya alam dan budaya, 2) industri yang terdiri dari core creative industry dan backward and forward linkage creative industry, 3) pembiayaan, 4) teknologi dan infrastruktur, dan 5) pemasaran. Pilar-pilar ini diperkuat oleh keterlibatan unsur dalam penta-helix melalui kelembagaan berupa nilai, norma, peraturan, dan hukum perundangan yang mengatur interaksi para aktor-aktor utama (intelektual, bisnis, komunitas, media dan pemerintah) dalam pengembangan usaha ekonomi kreatif. Fondasi yang kokoh, pilar yang kuat dan kelembagaan yang harmonis menjadi kunci dalam pengembangan ekonomi kreatif. Dengan demikian hipotesis yang dibangun dalam penelitian ini adalah :

$\mathrm{H}_{2}$.Kebijakan pemerintah akan memperkuat pengaruh aliansi strategis terhadap keunggulan bersaing.

\section{METODE}

\section{Pendekatan Penelitian}

Penelitian ini termasuk jenis penelitian eksplanasi yang bertujuan menganalisis hubungan atau pengaruh suatu variabel terhadap variabel lainnya juga merupakan penelitian eksplanatori yang dimaksudkan untuk menjawab permasalahan yang sudah dirumuskan berdasarkan tujuan yang telah ditetapkan dan melakukan pengujian terhadap hipotesis. Ditinjau dari pendekatan analisisnya, penelitian ini menggunakan pendekatan kuantitatif yang mendasarkan pada pengujian teori yang melibatkan variabel-variabel, yang diukur dengan bilangan dan dianalisis dengan prosedur-prosedur statistik.

Penelitian ini dilakukan di wilayah Malang Raya yang meliputi Kota Malang, Kabupaten Malang dan Kota Batu dengan beberapa alasan yaitu:: 1) Kota Malang ditetapkan sebagai salah satu kota kreatif dari 10 kota kreatif di Indonesia; 2) Malang Raya merupakan destinasi wisata terkemuka di Jawa Timur dengan branding Shining Batu, Beautiful Malang dan Hearth of East Java (Kab. Malang) dan menjadi daerah pendukung Bromo-Tengger-semeru yang merupakan destinasi wisata prioritas nasional. 3) Usaha ekonomi kreatif menjadi pendukung pengembangan sektor pariwisata.

\section{Populasi dan Sampel Penelitian}

Populasi penelitian ini adalah UMKM bidang kerajinan di Malang Raya sebanyak 192 unit usaha (Dinas Koperasi dan UMKM Kab. Malang, Disperindag Kota Malang dan Kota Batu, 2018). Alasan pemilihan subsektor kerajinan sebagai obyek penelitian adalah: 1) Jumlah unit usaha terbesar ketiga dibidang usaha ekonomi kreatif; 2) Penyumbang tenaga kerja terbesar ketiga di bidang usaha ekonomi kreatif; 3) Penyumbang terbesar ketiga nilai tambah ekonomi kreatif; 4) Penyumbang terbesar kedua ekspor ekonomi kreatif; 5) Produk ekonomi kreatif yang paling banyak ketiga yang dikonsumsi masyarakat; 6) Jumlah usaha kerajinan di Kota Malang sebesar $32,5 \%$, Kabupaten Malang sebesar 60,4\% dan Kota Batu sebesar 29,4\% dari total usaha yang ada di masing-masing wilayah.

Untuk memperoleh ukuran sampel yang cukup representatif dipergunakan rumus Slovin. Persentase kelonggaran ketidaktelitian yang dipakai sebesar 5\%. Jumlah sampel yang diperoleh dari perhitungan rumus Slovin adalah 130. Teknik pengambilan sampel dilakukan menggunakan teknik pengambilan proportional area random sampling. Variabel, dimensi dan skala pengukuran dalam penelitian ini menggunakan skala Likert 7 poin. Terdapat 18 dimensi yang digunakan terdiri atas: 8 dimensi Aliansi Strategis yaitu motif: Posisi pasar dan akses pasar; Pengembangan Produk; memasuki pasar/produk baru; modifikasi struktur pasar; akselerasi, efisiensi sumberdaya; mengurangi resiko dan mengembangkan sumberdaya; Meningkatkan kemampuan (Varadarajan dan Cunningham, 1995); 5 dimensi Kebijakan 
Pemerintah Permodalan/ Pembiayaan; SDM; Pemasaran; Infrastruktur dan Teknologi; Kelembagaan dan HaKI. (Bekraf, 2015). dan 5 dimensi Keunggulan Bersaing Berkelanjutan yaitu kepemimpinan biaya; diferensiasi; VRIN; Manajemen; Kinerja (Porter, 1985; Suardhika, 2011; Chen et al., 2006) Pengumpulan data dilakukan dengan menggunakan kuesioner. Kuesioner diberikan kepada para pengusaha UMKM kerajinan. Selain pertanyaan tertutup, juga digunakan pertanyaan terbuka untuk memberikan dukungan kualitatif bagi data kuantitatif yang didapat dari pengumpulan data dan digunakan dalam pembahasan implikasi manajerial.

\section{Metode Analisis Data}

Metode analisis data yang digunakan aalah Analisis Statistik Deskriptif untuk menggambarkan karakteristik responden penelitian dan variabel yang digunakan dalam penelitian. Penggambaran secara deskriptif mengenai indikator-indikator konstruk dalam penelitian ini terutama dengan menggunakan nilai rata-rata (mean). Metode lain yang digunakan dalam penelitian ini adalah Analisis Statistik Inferensial dengan menggunakan model kausalitas atau hubungan pengaruh yang diuji dengan pendekatan SEM-PLS (Structural Equation Model-Partial Least Square) yang berbasis variance. Untuk mendukung akurasi hasil analisis kuantitatif, juga diggunakan metode interview untuk mengungkap bagaimana UMKM mengembangkan aliansi strategis yang dijalankan serta bagaimana peran kebijakan pemerintah dalam pengembangan usaha. Dengan melakukan wawancara diharapkan dapat memperkuat analisis kuantitatif.

\section{HASIL DAN PEMBAHASAN \\ Profil Usaha dan Deskripsi Responden}

Tabel 1 menunjukkan bahwa usaha ekonomi kreatif yang diteliti sebagian besar (72,31 persen) berdiri kurang dari 10 tahun. Gambaran mengenai lama usaha menunjukkan bahwa perkembangan usaha ekonomi kreatif dibidang kerajinan selama 10 tahun terakhir mengalami pertumbuhan yang signifikan yang dibuktikan dengan persentase lama usaha sampai dengan 10 tahun mencapai 72 persen. Artinya banyak dalam kurun waktu 10 tahun terakhir pertumbuhan usaha ekonomi kreatif kerajinan telah menjadi salah satu pilihan usaha yang ditekuni oleh masyarakat di Malang raya seiring dengan perkembangan ekonomi dan pariwisata.

Tabel 1. Profil Usaha

\begin{tabular}{lrr}
\hline \multicolumn{1}{c}{ Profil Usaha } & Jumlah & $\%$ \\
\hline Lama Usaha & & \\
$\leq 10$ tahun & 94 & 72,31 \\
$10-29$ tahun & 29 & 22,30 \\
$\geq 30$ tahun & 7 & 5,39 \\
& & \\
Omset/tahun & & \\
Mikro ( s/d 300 Juta) & 107 & 82,31 \\
Kecil (300 juta $-<2,5$ milyar) & 23 & 17,69 \\
\hline Sumber: Data primer diolah (2018) & &
\end{tabular}

Dari aspek omset penjualan per tahun, usaha yang diamati 82,31 persen termasuk usaha mikro. Dari sisi ketenagakerjaan, usaha ekonomi kreatif yang diteliti 93,85 persen masuk dalam kategori usaha kecil dengan jumlah tenaga kerja antara 4-19 tahun.

Tabel 2. Profil Responden

\begin{tabular}{|c|c|c|}
\hline Profil Responden & Jumlah & $\%$ \\
\hline \multicolumn{3}{|l|}{ Jenis Kelamin } \\
\hline Laki-laki & 45 & 34,6 \\
\hline Perempuan & 85 & 65,4 \\
\hline \multicolumn{3}{|l|}{ Umur } \\
\hline$<30$ tahun & 21 & 16,1 \\
\hline 30-49 tahun & 77 & 59,2 \\
\hline 40-49 tahun & 24 & 18,5 \\
\hline$\geq 50$ tahun & 8 & 6,2 \\
\hline \multicolumn{3}{|l|}{ Tingkat Pendidikan } \\
\hline Sampai dengan SD & 6 & 4,6 \\
\hline SMP sederajat & 14 & 10,8 \\
\hline SMA sederajat & 36 & 27,7 \\
\hline Diploma & 10 & 7,7 \\
\hline S1 & 57 & 43,8 \\
\hline$\geq \mathrm{S} 2$ & 7 & 5,4 \\
\hline
\end{tabular}

Sumber: Data primer diolah (2018)

Dilihat dari karakteristik responden penelitian ini menunjukkn bahwa rersponden penelitian terdiri atas 34,6 persen laki-laki dan 65,4 persen perempuan. Sekitar 59,2 persen atau 77 responden memiliki rentang usia 30-49 tahun. pengusaha muda (di bawah 30 tahun) di sektor ekonomi kreatif relatif 
masih minim karena dalam rentang usia tersebut, mereka cenderung masih ingin menuntut ilmu.

Ditinjau dari tingkat pendidikan 56,9 persen memiliki tingkat pendidikan paling tidak diploma, 27,7 persen berpendidikan SMA dan sederajat dan hanya 15,4 persen yang mempunyai tingkat pendidikan sampai dengan SMP dan sederajat. Tingkat pendidikan dan pengalaman usaha menjadi cerminan kemampuan responden dalam membuat keputusan strategis yang memberikan bekal bagi pemilik atau pengelola usaha untuk menggunakan ilmu, kapasitas dan pengalamannya dalam mengembangkan usaha.

\section{Deskripsi Variabel Penelitian \\ Hasil Analisis dan Evaluasi Model}

Pengujian Model Pengukuran dilakukan dengan menguji convergent validity, discriminant validity dan composite reliability. Hasil komputasi loading factor menunjukkan bahwa estimasi loading factor pada seluruh dimensi konstruk nilainya di atas 0,6 sehingga pengukuran konstruk memenuhi syarat validitas konvergen. Selain dilihat dari nilai faktor loading, convergent validity juga dapat dilihat dari nilai Average Variance Extracted (AVE).

Pada penelitian ini nilai AVE masingmasing konstruk berada di atas 0,5. Oleh karenanya tidak ada permasalahan convergent validity pada model yang diuji.

Tabel 3. Nilai Average Variance Extracted

\begin{tabular}{lccc}
\hline Variabel & AVE & $\begin{array}{c}\text { Cronbach's } \\
\text { Alpha }\end{array}$ & $\begin{array}{c}\text { Composite } \\
\text { Reliability }\end{array}$ \\
\hline AS & 0,597 & 0.902 & 0,922 \\
KP & 0,718 & 0,899 & 0,926 \\
KB & 0,573 & 0,810 & 0,869 \\
\hline
\end{tabular}

Keterangan: $\mathrm{AS}=$ Aliansi Strategis; $\mathrm{KP}=$ Kebijakan Pemerintah; KB=Keunggulan Bersaing

Selanjutnya, dilakukan pengujian discriminant validity. Metode lain untuk melihat discriminant validity adalah dengan melihat nilai square root of average variance extracted (AVE) dengan membandingkan nilai cr akar kuadrat AVE dengan nilai korelasi antar konstruk (Fornell-Larcker Criterion Nilai akar kuadrat dari AVE $(0,772$;
0,757; 0,847 dan 0,661) lebih besar dari korelasi antar konstruk. Untuk memastikan bahwa tidak ada masalah terkait pengukuran maka langkah terakhir dalam evaluasi outer model adalah menguji unidimensionalitas dari model dengan menggunakan Cronbach's Alpha dan Composite reliability. Dikatakan reliable jika Cronbach's Alpha lebih dari 0,6 dan Composite reliability lebih dari 0,70 sehingga dapat disimpulkan bahwa indikator pengukur konstruk adalah reliabel.

Selanjutnuya untuk Pengujian Model Struktural dengan melakukan Evaluasi $\mathrm{R}^{2}$ sebagai ukuran akurasi prediksi model atau untuk mengetahui kemampuan variabel eksogen menjelaskan besarnya variabel endogen. Chin (1998) menjelaskan kriteria batasan nilai $\mathrm{R}^{2}$ dalam tiga klasifikasi 0,67 diartikan substansial; 0,33 diartikan moderat dan 0,19 diartikan lemah.

\begin{tabular}{lll}
\multicolumn{2}{l}{ Tabel 4. Nilai $R$-Square } \\
\hline Variabel & R-Square & Keterangan \\
\hline AS & 0,041 & Lemah $<0,19$ \\
KB & 0,278 & Lemah $<0,19$ \\
\hline
\end{tabular}

Keterangan: $\mathrm{AS}=$ Aliansi Strategis; $\mathrm{KB}=$ Keunggulan Bersaing

\section{Deskripsi variable dan evaluasi loading factor}

Persepsi pemilik/pengelola UMKM ekonomi kreatif terhadap variabel penelitian masuk dalam kategori cukup tinggi kecuali kebijakan pemerintah yang dikategorikan cukup rendah. Persepsi tertinggi terhadap variabel aliansi strategis, keunggulan bersaing dan yang terrendah dukungan kebijakan pemerintah.

Evaluasi nilai loading factor bertujuan untuk mengetahui pengukur variabel yang terkuat dari setiap dimensi. Nilai loading factor tertinggi menunjukkan dimensi pengukur variabel yang terkuat atau dapat diinterpretasikan sebagai dimensi yang memiliki kontribusi dominan dalam merefleksikan variabel. Indikator motif memasuki pasar-produk baru, kebijakan fasilitasi pemasaran; dan kemampuan mengelola usaha lebih baik, lebih inovatif dan image yang baik merupakan indikator dominan dalam merefleksikan aliansi 
strategis dan kebijakan pemerintah dan menjadi faktor kunci dalam meningkatkan keunggulan bersaing berkelanjutan UMKM ekonomi kreatif.

Tabel 5. Evaluasi Loading factor

\begin{tabular}{|c|c|c|c|}
\hline $\begin{array}{c}\text { Variabel } \\
\text { Penelitian }\end{array}$ & Dimensi & $\begin{array}{l}\text { Loading } \\
\text { factor }\end{array}$ & $\begin{array}{l}\text { Rata- } \\
\text { Rata }\end{array}$ \\
\hline Aliansi & Akses dan posisi pasar & 0,748 & 5,07 \\
\hline \multirow[t]{8}{*}{ Strategis } & Pengembangan produk & 0,743 & 5,08 \\
\hline & $\begin{array}{l}\text { Memasuki pasar- } \\
\text { produk baru }\end{array}$ & 0,841 & 5,00 \\
\hline & Struktur pasar & 0,783 & 4,73 \\
\hline & Akselerasi & 0,838 & 4,81 \\
\hline & Efisiensi sumberdaya)\ & 0,783 & 4,75 \\
\hline & $\begin{array}{l}\text { Mengurangi resiko dan } \\
\text { mengembangkan } \\
\text { sumberdaya }\end{array}$ & 0,796 & 4,88 \\
\hline & $\begin{array}{l}\text { Mmeningkatkan } \\
\text { keterampilan }\end{array}$ & 0,625 & 4,95 \\
\hline & & & 4,91 \\
\hline Kebijakan & Permodalan & 0,675 & 4,17 \\
\hline \multirow[t]{6}{*}{ Pemerintah } & Sumberdaya Manusia & 0,874 & 4,07 \\
\hline & Pemasaran & 0,901 & 3,90 \\
\hline & Penyediaan & 0,890 & 3,67 \\
\hline & Infrastruktur & & \\
\hline & $\mathrm{HaKI}$ & 0,875 & 3,47 \\
\hline & & & 3,86 \\
\hline Keunggulan & Kepemimpinan Biaya & 0,627 & 4,43 \\
\hline \multirow[t]{4}{*}{ Bersaing } & Diferensiasi & 0,742 & 5,00 \\
\hline & $\begin{array}{l}\text { Value, Rare, } \\
\text { Inimitable, } \\
\text { Nonsubstitution }\end{array}$ & 0,779 & 4,58 \\
\hline & $\begin{array}{l}\text { Kemampuan } \\
\text { mengelola usaha, lebih } \\
\text { inovatif dan image }\end{array}$ & 0,871 & 4,81 \\
\hline & $\begin{array}{l}\text { Kinerja profit, posisi, } \\
\text { pertumbuhan }\end{array}$ & 0,747 & 4,32 \\
\hline
\end{tabular}

Sumber: Data primer diolah (2018)

Dimensi motif memasuki pasarproduk baru menjadi dimensi yang memberikan kontribusi dominan dalam merefleksikan aliansi strategis dengan loading factor tertinggi masing-masing yaitu $(0,841 ; 5,00)$. Dimensi motif pasar-produk baru yang direfleksikan dengan aliansi membantu 1) memasuki domain produk baru; 2) memasuki domain pasar baru;3) memilih masuk atau bertahan dalam industri untuk menawarkan produk pengganti, atau pelengkap. Kebijakan memberikan fasilitasi pemasaran memberikan kontribusi dominan dalam merefleksikan kebijakan yang pemerintah berikan untuk pengembangan usaha ekonomi kreatif dengan nilai loading factor tertinggi $(0,901 ; 3,90)$. Dimensi ini direfleksikan dengan pemerintah memberikan fasilitasi: 1) penyelenggaraan dan/atau partisipasi dalam eksibisi, pameran/promosi dalam dan luar negeri; 2) Pengembangan pusat ekshibisi dan market place/market aggregator 3) fasilitasi/bimtek desain produk Indikasi Geografis (HKI); 4) Roadmap pengembangan e-commerce.

Kemampuan mengelola usaha memberikan kontribusi dominan dalam merefleksikan keunggulan bersaing berkelanjutan dengan nilai loading factor tertinggi $(0,871 ; 4,81)$. Dimensi ini direfleksikan dengan kemampuan perusahaan untuk: 1) Lebih inovatif dibanding pesaing, 2) memberikan Image/citra lebih baik dibanding pesaing dan 3) mengelola usaha lebih baik dibanding pesaing.

\section{Pengujian Hipotesis}

Hasil pengujian hipotesis menggunakan warpPLS 6.0 ditunjukkan pada Tabel 6. Cohen (1988) menyatakan nilai $\mathrm{R}^{2}$ 0,$02 ; 0,15$ dan 0,35 masing-masing mewakili efek kecil, sedang, dan besar.

Tabel 6. Hasil Analisis Uji Hipotesis

\begin{tabular}{lllll}
\hline \multicolumn{1}{c}{ Jalur } & $\begin{array}{c}\text { Koefisie } \\
\mathrm{n} \text { jalur }\end{array}$ & \multicolumn{1}{c}{$\begin{array}{c}\mathrm{P} \\
\text { Values }\end{array}$} & $\begin{array}{c}\text { Effect } \\
\text { Sizes }\end{array}$ & \multicolumn{1}{c}{ Hasil } \\
\hline $\mathrm{AS} \rightarrow \mathrm{KB}$ & 0,322 & $<0,001$ & 0,125 & Signifikan \\
$\mathrm{KP} \rightarrow \mathrm{AS}$ & 0,201 & 0,009 & 0,041 & Signifikan \\
$\mathrm{KP} \rightarrow \mathrm{KB}$ & 0,342 & $<0,001$ & 0,139 & Signifikan \\
$\mathrm{KP} * \mathrm{AS}$ & 0,088 & 0,153 & 0,014 & Tidak \\
$\rightarrow \mathrm{KB}$ & & & & Signifikan \\
\hline
\end{tabular}

Keterangan: $\mathrm{AS}=$ Aliansi Strategis; $\mathrm{KP}=$ Kebijakan

Pemerintah; $\mathrm{KB}=$ Keunggulan Bersaing

Tabel 6 menunjukkan bahwa koefisien jalur pada hubungan antara aliansi strategis dengan keunggulan bersaing sebesar 0,322 dengan probabilitas ( $\mathrm{p}$-value) sebesar $<0,001$ lebih kecil dari 0,05 ( $\mathrm{p}>0,05)$. Hasil ini memberikan bukti empiris hipotesis 1 diterima artinya bahwa aliansi strategis berpengaruh signifikan terhadap keunggulan bersaing UMKM kerajinan di Malang Raya. Semakin tinggi aliansi strategis mampu meningkatkan keunggulan bersaing. Selanjutnya pengujian terhadap hipotesis 2 yang menyatakan bahwa kebijakan pemerintah akan memperkuat pengaruh aliansi strategis terhadap keunggulan bersaing menunjukkan bahwa koefisien jalur 
pada peran moderasi kebijakan pemerintah pada hubungan antara aliansi strategis dengan keunggulan bersaing berkelanjutan sebesar 0,088 dengan probabilitas ( $\mathrm{p}$-value) sebesar 0,153 lebih besar dari 0,05 $(\mathrm{p}<0,05)$. Hasil ini memberikan bukti empiris bahwa kebijakan pemerintah tidak memoderasi pengaruh aliansi strategis dengan keunggulan bersaing berkelanjutan UMKM kerajinan di Malang Raya.

\section{Pembahasan}

\section{Pengaruh aliansi strategis terhadap keunggulan bersaing}

Aliansi didasarkan pada tesis bahwa perusahaan harus bekerja sama untuk bersaing (Morgan dan Hunt, 1994). Fakta bahwa UMKM ekonomi kreatif tidak mungkin memiliki semua kemampuan dan sumberdaya untuk bersaing menjadi dasar untuk menjalin aliansi strategis. Kerja sama yang efektif, memungkinkan mitra aliansi untuk sukses menggabungkan sumberdaya mereka yang berkontribusi terhadap pengembangan keunggulan bersaing (Madhok dan Tallman, 1998). Pandangan faktor relasional menunjukkan bahwa kesuksesan pertukaran relasional dihasilkan dari karakteristik tertentu suatu hubungan (Mehta et al., 2006), termasuk kepercayaan, hubungan, komitmen, komunikasi, dan kerja sama (Muthusamy et al., 2007). Dengan demikian, pandangan relasional menunjukkan bahwa aliansi yang ditandai dengan kepercayaan, komitmen, komunikasi, dan kerja sama akan lebih berhasil dibanding yang tidak.

Beberapa penelitian menunjukkan bahwa selain motif untuk mendapatkan berbagai macam keahlian, keterampilan, teknologi dan lainnya untuk meningkatkan kemampuan perusahaan, pembentukan aliansi strategis dan kerjasama adalah terutama dimotivasi untuk mendapatkan keunggulan bersaing di pasar (Bleeke dan Ernst, 1991; Ohmae, 1986; Prahalad dan Hamel, 1990).

Kajian empirik untuk menguji pengaruh aliansi strategis terhadap keunggulan bersaing berkelanjutan merupakan pengembangan dari fakta bahwa kajian mengenai hubungan tersebut baik secara konseptual, studi kasus maupun pengujian secara empirik memberikan hasil yang bertolak belakang. Studi empirik Cui dan Jiao (2011) membuktikan bahwa aliansi strategis berpengaruh positif terhadap keunggulan bersaing berkelanjutan. Temuan tersebut memberikan dukungan terhadap hasil kajian studi kasus Dacin et al. (2007) dan studi konseptual (Varadarajan dan Cunningham, 1995; Dyer dan Singh, 1998; Ireland et al., 2002; Teng, 2007). Sebaliknya studi kasus (Palakshappa dan Gordon, 2007) dan kajian empirik (Park dan Ungson, 2001; Lynch, 1990; Zineldin dan Dodourova, 2006) memberikan hasil yang berbeda dan menunjukkan bahwa aliansi strategis berpengaruh negatif terhadap kinerja dan keunggulan bersaing. Kontradiksi ini, menjadi alasan pengujian kembali hubungan tersebut.

Temuan dalam penelitian ini menunjukkan bahwa aliansi strategis berpengaruh signifikan terhadap keunggulan bersaing berkelanjutan sehingga hipotesis diterima. Temuan penelitian ini menunjukkan bahwa aliansi strategi memberikan dampak (effect sizes $=0,125 / \mathrm{kecil}$ ) dalam meningkatkan keunggulan bersaing.

Temuan ini mendukung hasil penelitian sebelumnya yang menunjukkan bahwa aliansi strategis berdampak positif terhadap keberhasilan perusahaan dan keunggulan bersaing (Varadarajan dan Cunningham, 1995; Dyer dan Singh, 1998; Ireland et al., 2002; Teng, 2007; Dacin et al., 2007; Temuan ini diartikan bahwa aliansi strategis yang semakin meningkat berdampak pada peningkatan keunggulan bersaing UMKM usaha ekonomi kreatif terutama dalam kemampuan manajemen yang dicirikan dengan kemampuan untuk lebih inovatif, menciptakan image yang lebih baik dan kemampuan mengelola usaha secara lebih baik dibanding pesaing.

Bagi UMKM ekonomi kreatif yang yang menghadapi banyak keterbatasan dan kendala dalam mengembangkan usahanya seperti rendahnya kualitas sumberdaya 
manusia, terbatasnya akses pembiayaan, terbatasnya pemasaran, kemampuan manajemen dan teknologi yang rendah dan kelembagaan yang belum maksimal (BPS, 2015) dan bahwa tidak mungkin perusahaan memiliki semua kemampuan dan sumberdaya untuk bersaing terutama mengharuskan UMKM menerapkan aliansi strategis dari para stakeholder. Dorongan untuk melakukan aliansi yang dibangun UMKM ekonomi kreatif dalam penelitian ini adalah membantu UMKM ekonomi kreatif untuk mendapatkan akses dan posisi pasar, pengembangan produk, posisi dalam struktur industri, memasuki pasar dan produk baru, mengurangi resiko, efisiensi biaya, akselerasi dan meningkatkan keterampilan mampu menjadi pendorong UMKM ekonomi kreatif untuk meningkatkan keunggulan bersaing meskipun hanya memberikan kontribusi 12,5 persen.

Isu strategis terkait partisipasi para stakeholder ekonomi kreatif di Indonesia meliputi sinergi, koordinasi, dan kolaborasi antar aktor; kuantitas dan kualitas organisasi dan wadah kreatif. Inisiatif untuk berkumpul dan berorganisasi dari orang-orang kreatif untuk berkontribusi bagi pengembangan ekonomi kreatif saat ini semakin meningkat seperti yang terlihat dari terbentuknya berbagai forum, komunitas dan asosiasi. Pemerintah juga turut mendukung inisiasi forum. Sekarang ini telah semakin banyak lembaga perantara yang mewadahi pengembangan dan pemasaran industry kreatif. Permasalahan utama dari asosiasiasosiasi tersebut adalah penguatan dari segi SDM dan tata kelola organisasi. Sebagian besar asosiasi cenderung dikelola secara sukarela dan paruh waktu sehingga sulit mendapatkan hasil yang optimal.

Sementara itu bentuk aliansi yang ada di Malang Raya seperti Asosiasi Pengrajin Kota Malang, komunitas rajut, komunitas pengrajin kain perca dan lainnya. Hasil penelitian juga menunjukkan bahwa aliansi strategis yang dilakukan oleh UMKM ekonomi kreatif di Malang Raya selain dipicu oleh persaingan dan kondisi perubahan lingkungan juga didorong oleh kesadaran akan keterbatasan dan permasalahan yang dimiliki (bahan baku, kemampuan desain dan inovasi produk, pemasaran, teknologi dan lainnya) sehingga membutuhkan perusahaan lain melalui aliansi strategis agar mendapatkan banyak manfaat dan tetap dapat bertahan hidup. Hal ini sejalan dengan pendapat Street dan Cameron (2007) menyatakan bahwa agar berkembang, usaha kecil disarankan untuk mengembangkan hubungan dengan organisasi eksternal yang memiliki potensi untuk membantu pengembangan bisnis, kelangsungan hidup, dan pertumbuhan.

Keberadaan aliansi dipandang sebagai hal yang sentral bagi suatu perusahaan untuk menghadapi persaingan global dan untuk memasuki pasar baru (Vyas et al., 1995). Hal ini dibuktikan dengan kerjasama/aliansi yang telah dilakukan dengan berbagai pihak seperti pemasok, perusahaan lain maupun dengan berbagai instansi dan lembaga lain yang terkait. Motif UMKM melakukan aliansi strategis cukup tinggi dengan skor 4,91. Motif terbesar UMKM usaha ekonomi kreatif menjalin aliansi/kerjasama dengan pihak lain adalah motif pengembangan produk $(5,08)$ akses dan posisi pasar $(5,07)$ dan motif memasuki pasar-produk baru $(5,00)$.

Pandangan faktor relasional menunjukkan bahwa kesuksesan pertukaran relasional dihasilkan dari karakteristik tertentu suatu hubungan (Mehta et al., 2006), termasuk kepercayaan, hubungan, komitmen, komunikasi, dan kerja sama (Muthusamy et al., 2007). Dengan demikian, pandangan relasional menunjukkan bahwa aliansi yang ditandai dengan kepercayaan, komitmen, komunikasi, dan kerja sama akan lebih berhasil dibanding yang tidak.

Pandangan ini memberikan gambaran bahwa UMKM ekonomi kreatif akan memperoleh manfaat optimal dari aliansi strategis yang akan membantu meningkatkan keunggulan bersaing jika dalam aliansi tersebut ada unsur kepercayaan, hubungan, komitmen, komunikasi dan kerjasama yang semua unsur tersebut telah berjalan dengan baik. Yoshino dan Rangan (dalam Monczka 
et al., 1998) menyatakan bahwa aliansi stratejis membutuhkan beberapa kondisi, seperti adanya saling ketergantungan antar satu perusahaan dengan perusahaan mitra, kemauan untuk shared benefit diantara mereka dan adanya kemauan untuk menjalin partisipasi kerjasama yang berkelanjutan. Saxton (1997) juga menunjukkan bahwa keberhasilan atau kesuksesan aliansi ditentukan oleh tiga faktor, yaitu reputasi perusahaan, degree of shared decision making, dan kesamaan stratejik. Hal ini menunjukkan adanya faktor-faktor yang dapat mempengaruhi upaya perusahaan dalam membangun hubungan aliansi belum berjalan sebagaimana mestinya.

Kontribusi aliansi strategis terhadap peningkatan keunggulan bersaing yang kecil menunjukkan bahwa aliansi strategis yang dilakukan oleh UMKM ekonomi kreatif lebih dimanfaatkan untuk mengembangkan produk, memperoleh akses dan posisi pasar, memasuki pasar-produk baru dan meningkatkan keterampilan yang manfaatnya dirasakan belum maksimal. Hal ini juga mengindikasikan bahwa kondisi UMKM usaha ekonomi kreatif di Malang Raya saat ini masih dalam tahap mengembangkan produk dan pasar yang untuk mencapai tahap pertumbuhan masih membutuhkan waktu yang lama sehingga dampaknya tidak terlalu besar pada peningkatan keunggulan bersaing.

UMKM ekonomi kreatif masih harus berusaha keras dan terus mengembangkan aliansi strategis yang memberikan dampak besar dalam peningkatan keunggulan bersaing dan mengatasi hambatan UMKM dan permasalahan mendasar yang dihadapi UMKM yaitu bahan baku, kemampuan desain dan inovasi produk, pemasaran, teknologi dan lainnya. UMKM ekonomi kreatif perlu mengoptimalkan aliansi strategis yang dibangun untuk membantu mengembangkan usaha UMKM dalam penelitian ini dengan tujuan: 1) dalam konteks motif memasuki pasar-produk baru: a) memasuki domain produk baru; b) memasuki domain pasar baru; c) membantu untuk memilih masuk atau bertahan dalam industri untuk menawarkan produk pengganti, atau pelengkap.

\section{Peran moderasi kebijakan pemerintah pada pengaruh aliansi strategis terhadap keunggulan bersaing berkelanjutan}

Kajian teoritis dan empirik yang diadopsi untuk menguji peran variabel moderasi kebijakan pemerintah dalam penelitian ini adalah banyaknya proposisi dari literatur yang menyatakan bahwa peran pemerintah dibutuhkan, melalui rangkaian kebijakan ekonomi dalam pasar dengan persaingan yang tajam untuk mempertahankan iklim yang kondusif agar UKM dapat beroperasi dengan sukses dan menguntungkan (Dandago dan Usman, 2011;Jasra et al., 2011). Kang dan Park (2012) meneliti dampak kolaborasi antar perusahaan serta pengaruh langsung dan tidak langsung dukungan litbang pemerintah terhadap inovasi. Bukti menunjukkan bahwa kemitraan hulu secara signifikan terkait dengan inovasi UKM. Dukungan pemerintah melalui pendanaan proyek secara langsung dan tidak langsung mempengaruhi inovasi perusahaan dengan merangsang kolaborasi $\mathrm{R}$ dan $\mathrm{D}$ internal hulu dan hilir dalam negeri.

Jasra et al. (2011) menyimpulkan bahwa dukungan pemerintah memiliki dampak positif dan signifikan terhadap kesuksesan bisnis. Pengusaha masih belum puas dengan dukungan pemerintah sehingga pemerintah harus memainkan peran penting dengan memberi mereka lingkungan yang kondusif dan menciptakan iklim yang baik.

Sebaliknya penelitian lain menunjukkan bahwa di negara sedang berkembang kebijakan pemerintah menimbulkan kesan eksploitasi UKM, hubungan dan jaringan sehingga dapat menjadi penghalang pemanfaatan kekuatan dan sumberdaya (Harvie et al., 2010; Okpara, 2011). Sathe (2006) menyatakan bahwa peraturan pemerintah dan prosedur birokrasi bisa menghambat serta memfasilitasi kegiatan kewirausahaan bisnis baru. Di satu sisi pemerintah dapat membuat kebijakan yang dapat meningkatkan dan mendukung 
pertumbuhan teknologi, produk, dan solusi baru, di sisi lain, pemerintah bisa juga menghambat kinerja UKM ketika memperkenalkan kebijakan yang dapat membatasi otonomi, serta kebebasan kewirausahaan apalagi bagi usaha dengan pertumbuhan dan lingkungan yang sangat dinamis. Bukti lainnya adalah adanya dampak negatif aliansi strategis terhadap keunggulan bersaing ((Park dan Ungson, 2001; Zineldin dan Dodourova, 2006; Palakshappa dan Gordon, 2007) sehingga diharapkan peran kebijakan pemerintah dapat menjembatani lack yang muncul dan mengoptimalkan aliansi strategis.

Variasi hasil penelitian mengenai kebijakan pemerintah perlu dikaji lebih lanjut dengan menjadikan sebagai variabel moderasi bagi pencapaian keunggulan bersaing terutama jika dikaitkan dengan peran pentingnya dalam meningkatkan daya saing dan mengembangkan ekonomi negara. Berdasarkan hasil pengujian peran moderasi kebijakan pemerintah pada pengaruh aliansi strategis terhadap keunggulan bersaing menunjukkan bahwa kebijakan pemerintah tidak memoderasi pengaruh aliansi strategis terhadap keunggulan bersaing berkelanjutan sebagai sehingga hipotesis 2 ditolak. Peran moderasi kebijakan pemerintah pada pengaruh aliansi strategis terhadap keunggulan bersaing yang tidak signifikan membuktikan bahwa kebijakan pemerintah melalui fasilitasi pengembangan SDM, pemasaran, infrastruktur dan teknologi serta HaKI dan kelembagaan belum mampu memperkuat pengaruh aliansi strategis terhadap keunggulan bersaing. Selain itu hasil penelitian ini juga menunjukkan bahwa kebijakan pemerintah justru berperan sebagai driver untuk meningkatkan aliansi strategis dan sebagai prediktor keunggulana bersaing. Peran kebijakan pemerintah sebagai driver aliansi strategis dengan koefisien jalur 0,201 (effect sizes: 0,041) lebih kecil dibanding dengan peran prediktor keunggulan bersaing dengan koefisien jalur 0,342 (effect sizes: 0,139) dan lebih besar dibanding peran moderasi pada pengaruh aliansi strategis terhadap keunggulan bersaing berkelanjutan dengan koefisien jalur 0,088 (effect sizes: 0,014). Hasil ini berarti bahwa efektifitas dukungan dan kebijakan pemerintah akan berpengaruh pada peningkatan aliansi strategis dan keunggulan bersaing UMKM ekonomi kreatif.

Bukti empirik bahwa kebijakan pemerintah menjadi driven aliansi strategis dan predictor keunggulan bersaing sejalan dengan temuan yang menyatakan bahwa dukungan pemerintah akan meningkatkan kemampuan inovasi perusahaan dan merangsang kolaborasi (Kang dan Park, 2012) afiliasi dan kesuksesan bisnis (Jasra et al., 2011). Temuan ini menunjukkan bahwa kebijakan pemerintah berperan dalam meningkatkan aliansi strategis dan keunggulan bersaing UMKM ekonomi kreatif. Peran tersebut menjadi sangat penting ketika usaha ekonomi kreatif menghadapi banyak masalah. Fakta ini diungkapkan oleh BEKRAF yang menyatakan bahwa dalam konteks penciptaan nilai tambah kreatif yang berfokus pada industri kreatif, ekonomi kreatif masih dihadapkan pada beberapa tantangan besar yang dapat menghambat pertumbuhannya, terkait dengan 1) wirausaha kreatif, yaitu masih relatif rendahnya tingkat profesionalisme, baik dari segi keterampilan maupun keahlian (skill), pengetahuan (knowledge) maupun sikap dan perilaku (attitude), serta akses terhadap kesempatan bekerjasama dan berjejaring dengan pelaku kreatif lainnya baik di tingkat lokal, nasional, dan global; 2) jumlah usaha di Indonesia relatif rendah jika dibandingkan dengan negara-negara dengan industri kreatif yang sudah berkembang. 3) produk dan karya kreatif, yaitu meskipun keunikan dan kreativitas karya dan produk kreatif Indonesia telah diakui oleh pasar global, awareness pasar mengenai produk dan karya kreatif Indonesia masih rendah akibat rendahnya keberlanjutan produksi dan kemampuan untuk melakukan branding, mengembangkan kemasan dan keragaman, dan menghasilkan produk dan karya kreatif yang ramah lingkungan (eco-product). 
Peran pemerintah sebagai prediktor dengan koefisien jalur yang lebih besar dibanding dengan peran moderasi mengindikasikan pentingnya untuk meningkatkan dukungan pemerintah dalam pengembangan ekonomi kreatif guna meningkatkan aliansi strategis dan keunggulan bersaing. Persepsi UMKM terhadap kebijakan pemerintah yang masuk dalam kategori cukup rendah $(3,86)$ memberikan arti bahwa dukungan kebijakan pemerintah untuk pengembangan UMKM kerajinan masih belum optimal terutama dalam hal penyediaan infrastruktur $(3,67)$, fasilitasi HaKI $(3,47)$, fasilitasi pemasaran $(3,90)$. Dalam konteks pencapaian keunggulan bersaing berkelanjutan, dukungan kebijakan pemerintah yang penting adalah kebijakan fasilitas pemasaran dengan loading factor tertinggi $(0,934)$. Hal ini sejalan dengan fakta bahwa permasalahan mendasar ekonomi kreatif adalah pemasaran (Bekraf, 2015).

Pemerintah melalui Bekraf telah mengembangkan kebijakan dan program terkait fasilitasi riset, edukasi, dan pengembangan di bidang Ekonomi Kreatif. Beberapa program dan kebijakan pemerintah dalam mengembangkan usaha ekonomi kreatif adalah : membangun Pusat Unggulan Ekonomi Kreatif untuk memperkuat fondasi di sektor Ekraf Indonesia dan menjalankan beberapa program yang tertuang di dalamnya. Di bidang permodalan, guna meningkatkan daya saing UMKM Kreatif, membantu penanggulangan kemiskinan dan perluasan kesempatan kerja serta peningkatan nilai tambah pelaku di Subsektor Ekraf, Bekraf memfasilitasi dan menjembatani para pelaku Ekraf dengan pihak perbankan konvensional dan perbankan syariah. Dibidang infrastruktur, Bekraf menyediakan ruang dan sarana untuk menumbuhkembangkan potensi subsektor Ekonomi Kreatif di suatu wilayah. program utamanya adalah Banper (Bantuan Pemerintah) dalam bentuk Fasilitasi Revitalisasi Infrastruktur Fisik Ruang Kreatif, Sarana Ruang Kreatif, dan Teknologi Informasi dan Komunikasi (TIK) serta membangun jaringan kota kreatif yang memungkinkan pelaku usaha Ekraf untuk dapat saling berinteraksi dan berkolaborasi dengan mudah. Di bidang pemasaran dengan tujuan untuk memperluas pasar produk dan jasa kreatif Indonesia sehingga kompetitif di pasar global. Strategi yang dilakukan termasuk exhibition, promosi dan branding produk dan jasa kreatif Indonesia, misi dagang business to business, perluasan jejaring antar wirausaha dan usaha kreatif, diplomasi budaya sebagai softpower, fasilitasi kemitraan dengan ritel modern untuk mendistribusikan produk kreatif.dan membangun citra produk nasional secara menyeluruh dan konsisten baik di Indonesia maupun di luar negeri.. Di bidang HKI, Regulasi dan kelembagaan dilakukan dengan tujuan untuk membangun kesadaran serta ekosistem Hak kekayaan intelektual (HKI) nasional. Program-programnya diantaranya penyediaan informasi tentang HKI dalam bentuk aplikasi, membentuk Satgas antipembajakan, menghadirkan para konsultan HKI untuk memberikan konsultasi one-onone secara gratis, serta menyediakan fasilitasi untuk pendaftaran HKI bagi para pelaku Ekraf, fasilitas sertifikasi profesi bagi pelaku Ekraf, membantu pembentukan regulasi daerah terkait pengembangan Ekraf dan membantu untuk pendirian badan hukum untuk usaha Ekraf serta merumuskan, menetapkan, mengkordinasikan dan sinkronisasi kebijakan dan program hubungan antar lembaga dan wilayah baik di dalam dan luar negeri guna membangun ekosistem Ekonomi Kreatif di Indonesia yang melibatkan para akademisi, komunitas, media, bisnis, dan pemerintah baik dari dalam maupun luar negeri. Kelembagaan tidak hanya mencakup regulasi yang mendukung penciptaan iklim yang kondusif untuk berkembangnya industri kreatif, namun juga meliputi adanya partisipasi aktif pemangku kepentingan, pengarusutamaan kreativitas, partisipasi aktif dalam forum internasional serta terciptanya apresiasi terhadap orang, karya, wirausaha, dan usaha kreatif lokal dan sumberdaya alam dan budaya lokal. 
Dalam upaya memetakan dan mengembangkan potensi Ekonomi kreatif di daerah, Bekraf menggunakan prinsip "3C: Connect-Collaborate-Commerce"

(Keterhubungan-Kolaborasi-Komersialisasi) bagi seluruh pemangku kepentingan, dari skala local hingga nasional, dan dengan melibatkan unsur Pentahelix yaitu Academician, Businesses, Community, Government, dan Media. Connect adalah kegiatan berupa Penandatanganan Nota Kesepahaman. Kolaborasi dan Komersialisasi dilakukan dengan melakukan Focus Group Discussion (FGD) Pentahelix.

Pemerintah telah menetapkan regulasi untuk mendukung penciptaan Iklim usaha yang kondusif guna mengembangkan ekonomi kreatif, namun masih perlu terus diupayakan dan ditingkatkan dalam implementasinya mengingat banyak kalangan usaha ekonomi kreatif yang belum tersentuh dan hanya sedikit yang merasakan manfaatnya. Beberapa regulasi untuk pengembangan ekonomi kreatif yang perlu ditingkatkan efektifitasnya mencakup: 1) regulasi terkait lingkungan pendidikan dan apresiasi terhadap kreativitas (nurturance environment), 2) regulasi pengembangan sumberdaya bagi industri kreatif; 3) regulasi terkait penciptaan nilai kreatif dan penataan usaha ekonomi kreatif dan industri pendukung penciptaan nilai kreatif (backward and forward linkage); 4) regulasi pembiayaan bagi usaha ekonomi kreatif; 5) regulasi perluasan pasar karya kreatif; 6) regulasi pengembangan dan penyediaan teknologi dan infrastruktur pendukung usaha ekonomi kreatif dan 7) regulasi terkait Hak Kekayaan Intelektual (HKI).

Isu strategis terkait partisipasi para pemangku kepentingan ekonomi kreatif meliputi sinergi, koordinasi, dan kolaborasi antar aktor(intelektual, bisnis, komunitas, media dan pemerintah); kuantitas dan kualitas organisasi dan wadah kreatif (ketersediaan, kesesuaian, dan sebaran; SDM pengelola lembaga, kualitas tata kelola organisasi lembaga). Partisipasi dan sinergi para pemangku kepentingan ekonomi kreatif secara umum masih lemah.
Media massa sebagai corong komunikasi ke masyarakat belum memiliki pemahaman yang kuat mengenai ekonomi kreatif walaupun saat ini sudah semakin banyak porsi pemberitaan mengenai ekonomi kreatif namun masih sering dimasukkan sebagai porsi berita budaya, seni atau hiburan. Pemerintah sebagai pembuat kebijakan dan fasilitator telah mengembangkan berbagai program untuk mendorong kemajuan ekonomi kreatif. Namun demikian, efektivitas dan tingkat keberhasilan program-program tersebut masih belum optimal. Hal ini disebabkan antara lain oleh minimnya sinergi antara Pemerintah, komunitas, intelektual, media dan bisnis. Koordinasi lintas instansi kementerian masih lemah sehingga mengakibatkan terjadinya tumpang tindih program. Dalam rangka pengarusutamaan kreativitas, diperlukan gerakan pengarusutamaan kreativitas yang dapat meningkatkan apresiasi masyarakat, bisnis, pendidikan, dan pemerintahan terhadap kreativitas. Kebutuhan yang sangat penting dan mendesak tersebut, mengharuskan pemerintah untuk meningkatkan efektivitas fasilitasi dan kebijakan pemerintah dalam rangka pembinaan dan pengembangan sehingga kemandirian usaha ekonomi kreatif dapat tercapai dan dapat meningkatkan perekonomian rakyat sehingga mampu meningkatkan pendapatan, membuka lapangan pekerjaan, dan mensejahterakan masyarakat secara keseluruhan.

\section{Kesimpulan}

Temuan penelitian berhasil membuktikan adanya model konseptual yang terintegrasi antara aliansi strategis, kebijakan pemerintah dan keunggulan bersaing. Dengan menggunakan pendekatan konfigurasi dalam mengintegrasikan aliansi strategis dan kebijakan pemerintah ternyata memberikan kontribusi $27,8 \%$ dalam menjelaskan keunggulan bersaing UMKM. Kontributor kebijakan pemerintah $(13,9 \%)$ dan aliansi strategis (12,5\%) terrhadap pencapaian keunggulan bersaing. Hasil ini menunjukkan bahwa efek kontingensi 
(interaksi dua arah) saja cenderung memberikan pemahaman yang parsial dan tidak lengkap terkait keunggulan bersaing sehingga perlu melibatkan variable lain.

Dengan memperluas studi sebelumnya, temuan dari penelitian ini menunjukkan bahwa peningkatan aliansi strategis bersama dengan peningkatan peran pemerintah yang lebih besar melalui dukungan dan kebijakannya meningkatkan keunggulan bersaing secara keseluruhan.. Fasilitasi dan kebijakan pemerintah yang lebih besar juga memungkinkan UMKM ekonomi kreatif mendapatkan banyak bantuan dalam pengembangan SDM, pemasaran, infrastruktur dan teknologi, HaKI dan kelembagaan serta pengembangan jaringan dan kerjasama untuk memastikan UMKM ekonomi kreatif mendapatkan posisi pasar yang tepat dari kepemimpinan biaya, diferensiasi produk unik yang dihasilkan, menghasilkan sumberdaya inti dengan karakteristik VRIN, mengelola usaha dengan lebih baik, mendapatkan keuntungan untuk mencapai keunggulan bersaing yang lebih besar. Dengan demikian, peneitian ini juga menambah literatur yang ada dengan menunjukkan bahwa ketika UMKM ekonomi kreatif dihadapkan pada permasalahan keterbatasan sumberdaya yang dimiliki, kegiatan aliansi strategis yang lebih kuat diperlukan secara bersamaan untuk mengimbangi keterbatasan tersebut, dan peran pemerintah dalam bentuk dukungan dan kebijakan yang lebih besar dapat memfasilitasi keberhasilan implementasi aliansi dan keunggulan bersaing.

Temuan penelitian ini juga mengkonfirmasi pandangan faktor-faktor relasional (Morgan dan Hunt, 1994; Spekman et al., 2000; Mehta et al., 2006; Muthusamy et al., 2007) bahwa perusahaan harus bekerja sama untuk bersaing. Kerja sama yang efektif, memungkinkan mitra aliansi untuk sukses menggabungkan sumberdaya sehingga dapat berkontribusi terhadap pengembangan keunggulan bersaing. Prinsip "3C: Connect-CollaborateCommerce" bagi seluruh pemangku kepentingan UMKM yang melibatkan unsur
Pentahelix yaitu Academician, Businesses, Community, Government, dan Media dalam pengembangan potensi Ekonomi kreatif mensyaratkan karakteristik tertentu bagi keberhasilan suatu hubungan (Mehta et al., 2006), seperti kepercayaan, hubungan, komitmen, komunikasi, dan kerja sama (Muthusamy et al., 2007). Hasil penelitian ini berkontribusi pada literatur yang ada dengan menunjukkan bahwa aliansi strategis yang dibangun di negara berkembang akan lebih berhasil dan berdampak besar pada keunggulan bersaing jika ada sinergi dari unsur-unsur dalam pentahelix dan dibangun atas dasar kepercayaan, komitmen, komunikasi, dan kerja sama yang efektif.

Temuan penelitian ini
mengkonfirmasi pendekatan struktural (I/O Theory) ( Porter, 1980; 1991; Caves dan Ghemawat, 1992; Grant, 1996) dan teori RBV (Penrose, 1959; Williamson, 1975; Teece, 1982, Wernerfelt, 1984; Barney, 1991; Grant, 1991; Peteraf, 1993; Amit dan Schoemaker, 1993; Prahalad dan Hamel, 1997). Sumberdaya utama UMKM ekonomi kreatif adalah kreativitas yang bersifat orisinil, unik dan terbarukan, sehingga menuntut pemilik/pengelola untuk terus meningkatkan orisinalitas, kreativitas, inovatif dan menemukan ide-ide baru untuk menghasilkan produk yang unik dan berbeda dari yang lain. Kombinasi efektif dari hasil yang diperoleh dengan menggunakan model I/O Theory melalui prinsip kepemimpinan biaya, diferensiasi dan model RBV berbasis sumberdaya inti ditambah dengan kemampuan lebih inovatif dan menciptakan citra/image yang lebih baik perusahaan dapat meningkatkan keunggulan bersaing.

Penelitian ini juga diharapkan dapat memberikan sumbangan pemikiran dan pengetahuan bagi pembina, pemerintah, pemilik dan pengelola usaha ekonomi kreatif dalam upaya meningkatkan keunggulan bersaing perusahaan melalui aliansi strategis dan kebijakan pemerintah. Agar UMKM yang beroperasi di Indonesia menerapkan secara berkelanjutan aliansi strategis yang tinggi, mereka membutuhkan dukungan kebijakan pemerintah yang lebih besar. 
Temuan bahwa kebijakan pemerintah memiliki pengaruh langsung terhadap aliansi strategis dan keunggulan bersaing menyiratkan bahwa pembuat kebijakan di negara berkembang harus memastikan bahwa ada upaya optimalisasi dari kegiatan fasilitasi, dukungan dan kebijakan pemerintah karena membantu UMKM untuk lebih baik menerapkan aliansi strategis. Pemerintah melalui kegiatan fasilitasi, dukungan dan kebijakan-kebijakan yang terkait dapat meningkatkan perannya dengan pengembangan ekonomi kreatif terutama dalam memfasillitasi kegiatan pemasaran dan menyediakan infrastruktur dan teknologi agar dapat meningkatkan keunggulan bersaing sekaligus dapat berperan sebagai driven yang mendorong peningkatan aliansi strategis yang dibangun oleh UMKM sehingga memberikan banyak manfaat terutama dalam mencapai keunggulan bersaing UMKM.

\section{DAFTAR PUSTAKA}

Amit, R., \& Schoemaker, P. J. . H. (1993). Strategic Asset and Organizational Rent. Strategic Management Journal, 14(1), 33-46.

Barney, J. (1991). Firm Resources and Sustained Competitive Advantage. Journal of Management, 17(1), 99-120.

Bharadwaj, S. G., Varadarajan, P. R., \& Fahy, J. (1993). Competitive Advantage in Service Industries: A Conceptual Model. Journal of Marketing, 57(4), 83-99.

Bleeke, J., \& Ernst, D. (1991). The way to win in cross-border alliances. Harvard Business Review, 69(6), 127-135.

Bridoux, F. (2004). A Resource-Based Approach to Performance and Competition: An Overview of The Connections between Resources and Competition.https://doi.org/10.1080/014 18630008221972

Caves, R. E., \& Ghemawat, P. (1992). Identifying Mobility Barrier. Strategic Management Journal, 13(1), 1-12.

Chen, Y. L., Shyh-B \& Wen, Chao T, (2006) The Influence of Green Innovation Performance on Corporate Advantage in Taiwan, Journal of Business Ethic, 67:331-339

Chin, W. W. (1998). The partial least squares approach for structural equation modeling. In Methodology for Business and Management. Modern methods for business research. (pp. 295-336). Mahwah, US: Lawrence Erlbaum Associates Publishers

Cui, Y., \& Jiao, H. (2011). Dynamic capabilities, strategic stakeholder alliances and sustainable competitive advantage: Evidence from China. Corporate Governance, 11(4), 386-398.

Dacin, M. T., Oliver, C., \& Roy, J.-P. (2007). The Legitimacy of Strategic Alliances: An Institutional Perspective. Strategic Management Journal, 28(1), 169-187.

Dandago, K. ., \& Usman, A. . (2011). Assesment of Governmant Industrialisation Policies on Promoting The Growth of Small Scale Industries In Nigeria. Phys. Rev. E, (November), 53.

Defee, C. C. (2006). Creating Competitive Advantage Using Non-Equity Strategic Alliances: A Small Company Perspective. Supply Chain Forum: An International Journal, 7(2), 44-57.

Denisi, A. S., Hitt, M. A., \& Jackson, S. E. (1998). The Knowledge-Based Approach to Sustainable Competitive Advantage. In Managing knowledge for competitive advantage (pp. 3-34).

Dyer, J. H., Kale, P., \& Singh, H. (2001). How to make strategic alliances work. MIT Sloan Management Review, 42(4), $37-43$.

Dyer, J. H., \& Singh, H. (1998). The Relational View: Cooperative Strategy and Sources of Interorganizational, Competitive Advantage. Academy of Management Review, 23(4), 660-679.

Eniola, A. A., \& Entebang, H. (2015). Government Policy and Performance of Small and Medium Business Management. International Journal of Academic Research in Business and Social Sciences, 5(2), 237-248. I

Grant, R. M. (1991). The Resource-Based Theory of Competitive Advantage: 
Implication for Strategy Formulation. California Management Review, (Spring 1991), 114-138.

Grant, R. M. (1996). Toward a knowledgebased view (KBV) theory. Strategic Management Journal, 17(Winter), 109122.

Hamel, G., Doz, Y. L., \& Prahalad, C. K. (1989). Collaborate with Your Competitors - and Win. Harvard Business Review, 67(1), 133-139.

Harash, E., Bin Yahya, S., Ries Ahmed, E., \& Jasem Alsaad, F. (2013). Impact of Government policies in the Influence of Market practices on Financial Performance of small and medium enterprises (SMEs) in Iraq. Journal of Accounting and Business (JAB), 13(2).

Harvie, C., Narjoko, D., \& Oum, S. (2010). Firm Characteristic Determinants of SME Participation in Production Networks. In ERIA Discussion Paper Series (Vol. 11).

Hitt, M. A., Hoskisson, R. E., \& Kim, H. (1997). International diversification: Effects on innovation and firm performance in product-diversified firms. Academy of Management Journal, 40(4), 767-798.

Hitt, M. A., Ireland, R. D., Camp, S. M., \& Sexton, D. L. (2001). Guest Editors ' Introduction To The Special Issue Strategic Entrepreneurship : Entrepreneurial Strategies For Wealth Creation. Strategic Management Journal, 491, 479-491.

Hitt, M. a., Keats, B. W., \& DeMarie, S. M. (1998). Navigating in the new competitive landscape: Building strategic flexibility and competitive advantage in the 21 st century. Academy of Management Perspectives, 12(4), 2242.

Ireland, R. D., Hitt, M. A., \& Vaidyanath, D. (2002). Alliance Management As a Source of Competitive Advantage. Journal of Management, 28(9), 413446.

Jasra, J. M., Khan, M. A., Hunjra, A. I., Ur Rchman, R. A., \& Azam, R. I. (2011).
Determinants of Business Success of Small and Medium Enterprises. International Journal of Business and Social Science, 2(20), 869-872.

Kang, K. N., \& Park, H. (2012). Influence of government $R \& D$ support and inter-firm collaborations on innovation in Korean biotechnology SMEs. Technovation, 32(1), 68-78.

Kanter, R. (1994). Collaborative advantage: the art of alliances. Harvard Business Review, 72(4), 96-108.

Le, N. T. B., \& Nguyen, T. V. (2009). The impact of networking on bank financing: The case of small and medium-sized enterprises in Vietnam. Entrepreneurship: Theory and Practice, 33(4), 867-887.

Lei, D., Slocum, J. W., \& Pitts, R. A. (1997). Building cooperative advantage: Managing strategic alliances to promote organizational learning. Journal of World Business, 32(3), 203-223.

Lynch, R. P. (1990). Building Alliances to Penetrate European Markets. Journal of Business Strategy, 11(2), 4-8.

Madhok, A., \& Tallman, S. B. (1998). Resources, Transactions and Rents: Managing Value Through Interfirm Collaborative Relationships. Organization Science: pp. 326-339. Hanover, Md: INFORMS.

Mehta, R., Larsen, T., Rosenbloom, B., \& Ganitsky, J. (2006). The impact of cultural differences in U.S. businessto-business export marketing channel strategic alliances. Industrial Marketing Management, 35, 156-165.

Monczka, R. M., Petersen, K. J., Handfield, R. B., \& Ragatz, G. L. (1998). Success Factors in Strategic Supplier Alliances: The Buying Company Perspective. Decision Sciences, 29(3), 553-577.

Morgan, R. M., \& Hunt, S. D. (1994). The Commitment Trust Theory of Relationship Marketing. Journal of Marketing, 58, 20-38.

Muthusamy, S. K., White, M. A., \& Carr, A. (2007). An Empirical Examination of the Role of Social Exchanges in 
Alliance Performance. Journal of Managerial Issues, 19(1), 53-75.

Ohmae, K. (1986). Becoming a Triad Power : The New Global Corporation. International Marketing Review, 3(3), 7-20.

Okpara, J. O. (2011). Factors constraining the growth and survival of SMEs in Nigeria: Implications for poverty alleviation. Management Research Review, 34(2), 156-171.

Palakshappa, N., \& Gordon, M. E. (2007). Collaborative Business Relationships: Helping Firms to Acquire Skills and Economies to Prosper. Journal of Small Business and Enterprise Development, 14(2), 264-279.

Park, S. H., \& Ungson, G. R. (2001). Interfirm Rivalry and Managerial Complexity: A Conceptual Framework of Alliance Failure. Organization Science, 12(1), 37-53.

Penrose, E.(1959). The Theory of the Growth of the Firm. London, UK: Basil Blackwell and Mott.

Peteraf, M. A. (1993). The Cornerstoners of Competitive Advantage: A ResourceBased View. Strategic Management Journal, 14, 179-191.

Porter, M. E. (1980). Competitive Strategy: Techniques for Analyzing Industries and Competitors. The Free Press, New York.

Porter, M. E. (1991). Towards a dynamic theory of strategy. Strategic Management Journal, 12, 95-117.

Prahalad, C. K., \& Hamel, G. (1990). The Core Competence of the Corporation. Harvard Business Review, may-june, 117.

Salman, D. (2010). Rethinking of Cities, Culture and Tourism within a Creative Perspective. Revista de Turismo $Y$ Patrimonio Cultural, 8(3).

Sathe, S., \& Handley-Scharchler, M. (2006). Social and cultural factors in FDI flows : evidence from the Indian states. World Review of Entrepreneurship, Management and Sust. Development, 2(4), 323-334.
Saxton, T. (1997). The Effects of Partner and Relationship Characteristics on Alliance Outcomes. Academy of Management Journal, 40(2), 443-461.

Shariff, M. N. M., Peou, C., \& Ali, J. (2010). Moderating Effect of Government Policy on Entrepreneurship and Growth Performance of Small-Medium Enterprises in Cambodia. International Journal of Business and Management Science, 3(1), 57-72.

Street, C. T., \& Cameron, A. F. (2007). External relationships and the small business: A review of small business alliance and network research. Journal of Small Business Management, 45(2), 239-266.

Teece, D. J., Pisano, G., \& Shuen, A. (1997). Dynamic Capabilites and Strategic Management. Strategic Management Journal, 18(7), 509-533.

Teng, B. S. (2007). Corporate entrepreneurship activities through strategic alliances: A resource-based approach toward competitive advantage. Journal of Management Studies, 44(1), 119-142.

Treacy, M., \& Wiersema, F. (1993). Customer intimacy and other value disciplines. Harvard Business Review VO - 71, (1), 84.

Varadarajan, P. R., \& Cunningham, M. (1995). Strategic Alliances: A Synthesis of Conceptual Foundations. Journal of the Academy of Marketing Science, 23(24), 282-296.

Vyas, N. M., Shelburn, W. L., \& Rogers, D. C. (1995). An analysis of strategic alliances: Forms, functions and framework. Journal of Business \& Industrial Marketing, 10(3), 47-60.

Wernerfelt, B. (1984). A resource-based view of the firm. Strategic Management Journal, 5(2), 171-180.

Zineldin, M., \& Dodourova, M. (2006). Motivation, achievements and failure of strategic alliances: The case of Swedish auto-manufacturers in Russia. European Business Review, 17(5), 460-470. 